\title{
PERANCANGAN MODEL UNTUK PERAMALAN TINGKAT PERTUMBUHAN PEMBIAYAAN MELALUI METODE JARINGAN SARAF TIRUAN DI BNI SYARIAH
}

\author{
Orfyanny S Themba \\ Email : orfyanny.sthemba@stiem-bongaya.ac.id \\ Manajemen/STIEM Bongaya \\ Jl. Letjen. Pol. A. Mappaoudang No. 28 Makassar \\ Susianah Mokhtar \\ Email : susianah@stiem-bongaya.ac.id \\ Manajemen/STIEM Bongaya \\ Jl. Letjen. Pol. A. Mappaoudang No. 28 Makassar
}

\begin{abstract}
ABSTRAK
Tren perkembangan pembiayaan di Indonesia mulai meningkat namun cenderung melambat dari tahun ke tahun. Peramalan pertumbuhan pembiayaan pada bank syariah menjadi hal yang menarik karena naik turunnya pembiayaan akan berdampak pada perekonomian Indonesia. Tujuan dari penelitian ini melakukan peramalan pertumbuhan pembiayaan dalam jangka waktu setahun melalui metode Jaringan Saraf Tiruan pada data Bank BNI Syariah dari tahun 2015 sampai dengan 2019. Hasil dari peramalan diharapkan memberi informasi bagi bank untuk menunjang pengambilan keputusan dan menyiapkan strategi meningkatkan pembiayaan sehingga semakin besar laba yang akan diperoleh. Model peramalan dibuat berdasarkan metode peramalan dan ditujukan untuk digunakan pada aplikasi peramalan pembiayaan. Model Jaringan Saraf Tiruan memiliki nilai akurasi peramalan yang tinggi karena memiliki nilai error RMSE, MAPE yang minimum. Dari hasil peramalan menggunakan model Jaringan Saraf Tiruan menunjukkan terjadi peningkatan pembiayaan pada setiap bulannya untuk akad murabahah, mudharabah, musyarakah dan qardh. Hanya pembiayaan yang menggunakan ijarah yang mengalami penurunan drastis dibanding tahuntahun sebelumnya. Pembiayaan murabahah masih tetap mendominasi dibanding akad mudharabah, musyarakah, qardh dan ijarah selama tahun 2020
\end{abstract}

Kata Kunci: Jaringan Saraf Tiruan ;Pembiayaan

\section{ABSTRACT}

Trend of financing development in Indonesia is starting to increase but tends to slow down from year to year. It is interesting to forecast the growth of financing in Islamic banks because the up and down of financing will have an impact on the Indonesian economy. The purpose of this study to forecast financing growth within a year through the Neural Network method on BNI Syariah Bank data from 2015 to 2019. The results of the forecast are expected to provide information for banks to support decision making and prepare strategies to increase financing so that greater profits that will be obtained. The forecasting model is made based on the forecasting method and is intended for use in financing forecasting applications. The Artificial Neural Network Model has a high value of forecasting accuracy because it has a minimum error value of RMSE, MAPE. The results of forecasting using the Artificial Neural Network model show an increase in financing every month for murabahah, mudharabah, musyarakah and qardh contracts. Only financing using ijarah has experienced a drastic decline compared to previous years. Murabahah financing still dominates over the mudharabah, musyarakah, qardh and ijarah contracts during 2020

Keyword: Arificial Neural Network ;Financing 


\section{PENDAHULUAN}

Potensi perbankan syariah di Indonesia relatif besar. Indonesia saat ini berada di urutan kesembilan dari 10 negara Islam lainnya, dari sisi aset industri jasa keuangan syariah.(Momentum B. Islamic Finance Development Report 2018 Building Momentum, 2018). Hingga Mei 2019 menurut data yang dipublikasikan oleh Otoritas Jasa Keuangan (OJK) pada Sharia Banking Statistics menunjukkan jumlah bank syariah sebanyak 13 bank, unit usaha syariah sejumlah 21, dan 166 bank perkreditan bank syariah.Tren pertumbuhan DPK pada Januari sampai dengan Mei 2019 mengalami kenaikan dibandingkan dengan posisi pada periode yang sama tahun lalu (Otoritas Jasa Keuangan, 2019). Pembiayaan syariah mengalami pertumbuhan namun cenderung melambat dari tahun sebelumnya. Pembiayaan konsumsi paling besar dibandingkan modal kerja dan investasi.

Pembiayaan merupakan salah satu tugas pokok bank, yaitu pemberian fasilitas penyediaan dana untuk memenuhi kebutuhan pihak-pihak yang defisit. Dari kegiatan pembiayaan diharapkan bukan hanya memberikan keuntungan bagi perbankan syariah saja namun juga mampu menjadi katalisator perkembangan ekonomi masyarakat, sehingga roda perekonomian suatu negara dapat berputar dengan lancar, dan pada akhirnya berdampak pada stabilitas dan pertumbuhan ekonomi yang baik. Ini dibuktikan oleh hasil penelitian yang dilakukan oleh M. Iman Taufik, Mohammad Soekarni, dan Hayati bahwa pertumbuhan pembiayaan pada bank syariah bepengaruh terhadap pertumbuhan ekonomi di Indonesia (Taufik, 2017) (Soekarni, 2014) (S, Ayyubi L, Anggraeni AD, 2017) (Sapar Sapar, Nuraeni Nonji, 2014)

PT. BNI Syariah merupakan salah satu bank syariah terbesar di Indonesia yang kinerjanya menjadi tolak ukur penilaian masyarakat akan kinerja bank syariah di Indonesia. PT BNI Syariah sampai triwulan I 2019 memperoleh laba bersih sebesar Rp 135 miliar atau naik 43,26\% secara tahunan dari periode sama $2018 \mathrm{Rp} 94,4$ miliar. Pembiayaan tertinggi dicatat oleh pembiayaan komersial 73,7\% menjadi Rp 7,79 triliun dari periode sama 2018 Rp 4,5 triliun dari lima sektor pembiayaan yaitu komersial, SME, konsumer, mikro dan hasanah card (BNI Syariah, 2019).

Untuk mempertahankan kinerja yang sudah baik dan tercapainya target pangsa pasar serta mampu bersaing dengan kompetitornya, BNI Syariah perlu melakukan peramalan pembiayaan sebagai indikator pertumbuhan bank. Peramalan pada dasarnya 
merupakan dugaan mengenai terjadinya suatu kejadian atau peristiwa di waktu yang akan datang. Peramalan diperlukan untuk penyesuaian bank terhadap perubahan lingkungan dan dapat digunakan sebagai pengambilan keputusan.

Penggunaan metode peramalan pertumbuhan pembiayaan dengan jaringan saraf tiruan (JST) belum pernah dilakukan sebelumnya. JST merupakan metode baru yang dikembangkan pada kasus peramalan dengan pemodelan hubungan yang kompleks antara input dan output dengan tujuan untuk menemukan pola pada data. JST banyak diaplikasikan pada sales forecasting karena kelebihannya pada control area, prediksi dan pengenalan pola.

Penelitian terkait peramalan pembiayaan yang sudah ada dilakukan oleh Ratna Candra Ika, Budi Darma Setiawan, Marji dengan judul Optimasi Fuzzy Time Series Menggunakan Algoritme ParticleSwarm Optimization untuk Peramalan Nilai Pembayaran Penjaminan Kredit Macet tahun 2018 meramalkan nilai pembayaran penjaminan klaim kredit macet sebagai bahan pertimbangan untuk menentukan nominal yang harus disediakan untuk bulan selanjutnya oleh lembaga penjaminan kredit menggunakan metode Fuzzy Time Series Untuk menghasilkan peramalan yang lebih baik, dilakukan optimasi menggunakan algoritma Particle Swarm Optimization (PSO), karena algoritme PSO memiliki desentralisasi yang tinggi dengan implementasi yang sederhana sehingga dapat menyelesaikan permasalahan optimasi secara efisien (RC \& BD, 2018). Sementara Barep Budi Irawan dan Daryanto dengan judul Sistem peramalan perkreditan di Bank Muamalat Jember dengan menggunakan Metode Single Moving Average meramalkan hasil perkreditan dengan metode Single Moving Averages (BB, 2019).

\section{METODE PENELITIAN}

\section{Jenis Penelitian}

Penelitian ini merupakan penelitian terapan (applied research) yaitu melakukan peramalan mengguanakan metode Jaringan Syaraf Tiruan (JST) pada variabelvariabel data pembiayaan di BNI Syariah.

\section{Data dan Variabel}

Data yang digunakan pada penelitian ini adalah data sekunder yang diperoleh melalui halaman website https://www.bnisyariah.co.id/id-id/ pada bagian laporan bulanan. Variabel yang akan dilakukan peramalan adalah variabel pembiayaan seperti pembiayaan sewa dan pembiayaan bagi hasil dari tahun 2015 Maret sampai 2019 Desember 


\section{Tahapan Penelitian}

\subsection{Tahapan Persiapan}

Tahapan persiapan pada penelitian ini sebagai berikut

a. Melakukan studi literatur yang menunjang penelitian, yaitu mengumpulkan serta mengkaji semua literatur yang berhubungan dengan teknik peramalan di Perbankan Syariah

b. Mengumpulkan data pembiayaan baik pembiayaan sewa maupun pembiayaan bagi hasil

\subsection{Tahapan Analisis Data}

Tahapan analisis data pada penelitian ini adalah

a. Melakukan manajemen dan eksplorasi data dari portal website BNI Syariah dengan analisis deskriptif baik berupa tabel maupun bentuk grafik terhadap semua variabel yang berkaitan dengan pembiayaan

b. Mengidentifikasi jenis pola data yang dimiliki.

c. Melakukan Analisis Statistika Inferensial berupa peramalan kuantitatif dengan metode peramalan Jaringan Syaraf Tiruan (JST).

d. Melakukan evaluasi metode yaitu melihat tingkat akurasi peramalan metode Jaringan Syaraf Tiruan

e. Melakukan interpretasi terhadap hasil peramalan pembiayaan

\section{HASIL DAN PEMBAHASAN}

\section{Data Pembiayaan}

Data yang digunakan pada penelitian ini adalah data Pembiayaan pada Bank BNI Syariah periode tahun 2015-2019. Data diperoleh dari laporan keuangan BNI Syariah. Data produk pembiayaan dengan akad mudharabah, musyarakah, murabahah, qardh, dan ijarah ditunjukkan pada Tabel 1 :

Tabel 1 Pembiayaan BNI Syariah

Periode Jan 2017-Des 2019

\begin{tabular}{rrrcrc}
\hline Bulan & \multicolumn{5}{c}{ Akad } \\
\hline & Mudarabah & Musyarakah & Murabahah & Qardh & Ijarah \\
\hline Mar-15 & 1.102 .744 & 1.500 .932 & 19.481 .558 & 576.639 & 380.808 \\
Apr-15 & 1.130 .894 & 1.593 .979 & 19.980 .931 & 57.459 & 364.355 \\
Mei-15 & 1.159 .346 & 1.599 .398 & 20.345 .471 & 581.231 & 349.807
\end{tabular}




\begin{tabular}{|c|c|c|c|c|c|}
\hline Jun-15 & 1.253 .877 & 1.697 .050 & 20.738 .288 & 588.276 & 334.972 \\
\hline Jul-15 & 1.287 .006 & 1.678 .608 & 20.718 .271 & 603.594 & 320.066 \\
\hline Agu-15 & 1.289 .921 & 1.725 .583 & 20.941 .560 & 590.729 & 305.172 \\
\hline Sep-15 & 1.288 .057 & 1.783 .117 & 21.028 .221 & 621.696 & 290.879 \\
\hline Okt-15 & 1.284 .681 & 1.764 .045 & 21.173 .110 & 610.431 & 276.014 \\
\hline Nov-15 & 1.283 .994 & 1.872 .205 & 21.413 .257 & 584.662 & 26.519 \\
\hline Des-15 & 1.279 .950 & 2.168 .804 & 21.774 .588 & 582.834 & 247.675 \\
\hline Jan-16 & 1.256 .026 & 2.179 .779 & 21.784 .592 & 574.756 & 233.185 \\
\hline Feb-16 & 1.227 .737 & 2.249 .772 & 21.784 .949 & 496.223 & 222.303 \\
\hline Mar-16 & 1.233 .878 & 2.456 .887 & 22.033 .706 & 572.937 & 211.308 \\
\hline Apr-16 & 1.205 .314 & 2.542 .713 & 22.269 .179 & 564.393 & 20.134 \\
\hline Mei-16 & 1.267 .508 & 2.646 .017 & 22.558 .344 & 582.182 & 190.581 \\
\hline Jun-16 & 1.296 .899 & 2.732 .566 & 23.097 .149 & 610.254 & 178.599 \\
\hline Jul-16 & 1.275 .334 & 2.705 .805 & 23.057 .000 & 63.466 & 166.207 \\
\hline Agu-16 & 1.288 .257 & 2.659 .853 & 23.316 .353 & 56.986 & 153.835 \\
\hline Sep-16 & 1.293 .605 & 2.856 .345 & 23.752 .721 & 733.907 & 142.727 \\
\hline Okt-16 & 1.283 .365 & 2.832 .039 & 24.094 .529 & 79.143 & 133.413 \\
\hline Nov-16 & 1.260 .976 & 3.054 .661 & 24.539 .420 & 854.832 & 124.633 \\
\hline Des-16 & 1.198 .408 & 3.012 .748 & 24.980 .802 & 930.007 & 115.745 \\
\hline Jan-17 & 1.151 .775 & 2.733 .284 & 25.094 .813 & 943.293 & 109.115 \\
\hline Feb-17 & 1.140 .995 & 2.708 .301 & 25.701 .234 & 1.085 .613 & 101.946 \\
\hline Mar-17 & 1.102 .866 & 3.039 .940 & 26.066 .631 & 1.152 .977 & 95.632 \\
\hline Apr-17 & 1.086 .651 & 3.099 .560 & 26.297.177 & 1.202 .276 & 89.599 \\
\hline Mei-17 & 1.094 .308 & 3.349 .604 & 26.502 .020 & 1.169 .561 & 83.063 \\
\hline Jun-17 & 1.162 .679 & 3.640 .709 & 26.771 .636 & 1.377 .747 & 76.297 \\
\hline Jul-17 & 1.110 .447 & 3.760 .464 & 26.834 .489 & 1.326 .348 & 71.029 \\
\hline Agu-17 & 1.044 .047 & 3.681 .159 & 27.007.712 & 1.378 .695 & 65.582 \\
\hline Sep-17 & 991.129 & 3.679 .358 & 26.906 .534 & 1.433 .824 & 59.678 \\
\hline Okt-17 & 965.319 & 3.800 .501 & 27.002 .849 & 1.435 .302 & 55.245 \\
\hline Nov-17 & 917.069 & 3.918 .182 & 27.108 .159 & 1.382 .042 & 53.025 \\
\hline Des-17 & 888.794 & 4.586 .209 & 27.265 .631 & 1.479 .877 & 52.149 \\
\hline Jan-18 & 841.809 & 4.423 .275 & 27.127.095 & 1.471 .274 & 50.437 \\
\hline Feb-18 & 807.572 & 4.472 .819 & 27.218.232 & 1.443 .851 & 51.421 \\
\hline Mar-18 & 815.159 & 4.701 .713 & 27.313 .502 & 1.533 .556 & 52.507 \\
\hline Apr-18 & 893.742 & 4.674 .533 & 27.354 .722 & 1.688 .114 & 53.251 \\
\hline Mei-18 & 1.102 .847 & 5.137 .417 & 27.573 .081 & 1.685 .542 & 53.743 \\
\hline Jun-18 & 1.132 .183 & 5.548 .811 & 27.677 .458 & 1.477 .074 & 52.671 \\
\hline Jul-18 & 1.106 .093 & 6.047 .723 & 28.326 .818 & 1.571 .840 & 55.214 \\
\hline Agu-18 & 1.070 .332 & 6.238 .503 & 28.555.307 & 1.608 .067 & 55.228 \\
\hline Sep-18 & 1.034 .985 & 6.373 .592 & 28.829 .532 & 1.626 .504 & 55.768 \\
\hline Okt-18 & 1.000 .486 & 6.701 .964 & 29.023 .667 & 1.586 .571 & 56.149 \\
\hline Nov-18 & 968.612 & 6.812 .038 & 29.115 .003 & 1.625 .703 & 349.779 \\
\hline Des-18 & 949.077 & 7.325 .664 & 29.349 .587 & 1.563 .881 & 344.699 \\
\hline Jan-19 & 933.360 & 7.402 .579 & 29.229.017 & 1.443 .991 & 339.070 \\
\hline Feb-19 & 899.393 & 8.365 .508 & 29.485 .751 & 1.314 .174 & 334.935 \\
\hline
\end{tabular}




\begin{tabular}{lrllll} 
Mar-19 & 916.316 & 8.620 .493 & 29.587 .615 & 1.248 .536 & 329.812 \\
Apr-19 & 962.458 & 9.029 .964 & 29.697 .622 & 1.170 .375 & 324.071 \\
Mei-19 & 1.208 .770 & 9.247 .304 & 29.981 .436 & 1.691 .171 & 318.994 \\
Jun-19 & 1.168 .048 & 9.844 .328 & 29.967 .372 & 1.707 .103 & 313.912 \\
Jul-19 & 1.250 .165 & 9.765 .567 & 30.375 .384 & 1.498 .769 & 309.346 \\
Agu-19 & 1.275 .404 & 9.021 .081 & 30.611 .319 & 1.293 .730 & 304.796 \\
Sep-19 & 1.479 .553 & 9.487 .838 & 30.649 .480 & 1.427 .695 & 299.178 \\
Okt-19 & 1.434 .047 & 9.478 .640 & 30.577 .221 & 1.516 .619 & 295.255 \\
Nov-19 & 1.681 .668 & 9.738 .107 & 30.587 .326 & 1.300 .977 & 290.542 \\
Des-19 & 1.595 .373 & 9.917 .161 & 30.549 .867 & 1.653 .272 & 286.519 \\
\hline
\end{tabular}

\section{Deskripsi Data Pembiayaan}

Analisis deskriptif memberikan gambaran data jumlah Pembiayaan yang terhimpun dari 5 akad yaitu mudharabah, musyarakah, murabahah, qardh, ijarah. Pada tabel 2 menunjukkan dekriptif statistiknya sebagai berikut

\section{Tabel 2 Data Deskriptif Pembiayaan}

\begin{tabular}{rrrrrr}
\hline \multicolumn{1}{c}{ Statistics } & \multicolumn{1}{c}{ Mudarabah } & \multicolumn{1}{c}{ Musyarakah } & \multicolumn{1}{c}{ Murabahah } & \multicolumn{1}{l}{ Qardh } & \multicolumn{1}{c}{ Ijarah } \\
\hline nobs & 58.000000 & 58.000000 & 58.000000 & 58.000000 & 58.000000 \\
NAs & 0.000000 & 0.000000 & 0.000000 & 0.000000 & 0.000000 \\
Minimum & 0.807572 & 1.500932 & 19.481558 & 0.056986 & 0.020134 \\
Maximum & 1.681668 & 9.917161 & 30.649480 & 1.707103 & 0.380808 \\
1. Quartile & 1.009111 & 2.649476 & 22.683008 & 0.593945 & 0.057031 \\
3. Quartile & 1.275386 & 6.619871 & 28.975133 & 1.479176 & 0.305078 \\
Mean & 1.148816 & 4.649772 & 25.899764 & 1.086769 & 0.184114 \\
Median & 1.155560 & 3.680258 & 26.870511 & 1.271133 & 0.160021 \\
Sum & 66.631308 & 269.686799 & 1502.186298 & 63.032581 & 10.678594 \\
SE Mean & 0.023896 & 0.359454 & 0.449048 & 0.064422 & 0.015719 \\
LCL Mean & 1.100966 & 3.929978 & 25.000560 & 0.957766 & 0.152638 \\
UCL Mean & 1.196666 & 5.369567 & 26.798967 & 1.215772 & 0.215590 \\
Variance & 0.033118 & 7.494019 & 11.695364 & 0.240712 & 0.014330 \\
Stdev & 0.181983 & 2.737521 & 3.419849 & 0.490624 & 0.119709 \\
Skewness & 0.316437 & 0.714496 & -0.286154 & -0.532242 & 0.156282 \\
Kurtosis & 0.238009 & -0.936780 & -1.288199 & -1.001172 & -1.672532 \\
\hline
\end{tabular}

Tabel 2 menunjukkan nilai rata-rata jumlah mudharabah adalah 1.14 yang artinya jumlah dana yang diperoleh setiap bulan Rp.1.140.000.000.000 Untuk musyarakah mean 4.64 yang artinya jumlah dana yang diperoleh setiap bulannya Rp. 4.640.000.000.000 Pada murabahah nilai rata-rata adalah 25.89 yang artinya jumlah dana sebesar Rp. 25.890.000.000.000 qardh nilai rata-rata 1.08 hal ini berarti rata-rata setiap bulan menerima dana sebesar Rp. 1.080.000.000.000 Pembiayaan dengan akad ijarah memiliki nilai rata-rata 0.18 yang artinya pembiayaan rata-rata setiap bulan sebesar Rp. 180.000 .000 .000 
Jumlah penyaluran pembiayaan yang terendah dari semua akad pembiayaan yaitu pada akad ijarah sebesar 0.02 atau Rp. 20.000.000.000 pada bulan April 2016 sementara penyaluran pembiayaan dengan jumlah dana terbesar pada murabahah sebesar 30.64 atau Rp. 30.649.480.000.000 pada bulan September 2019 dalam kurun waktu 30 bulan.

Secara umum berdasarkan data Otoritas Jasa Keuangan penyaluran pembiayaan dengan akad murabahah memang paling mendominasi pembiayaan bank syariah di Indonesia yaitu sebesar hampir 50\%. Pada BNI Syariah murabahah mendominasi $62 \%$ dari total portofolio pembiayaan dibanding akad mudharabah, musyarakah, ijarah dan qardh. Akad murabahah banyak digunakan untuk transaksi pembiayaan rumah yang merupakan salah satu produk pembiayaan konsumer BNI Syariah karena risiko yang rendah dibandingkan akad mudharabah dan musyarakah.

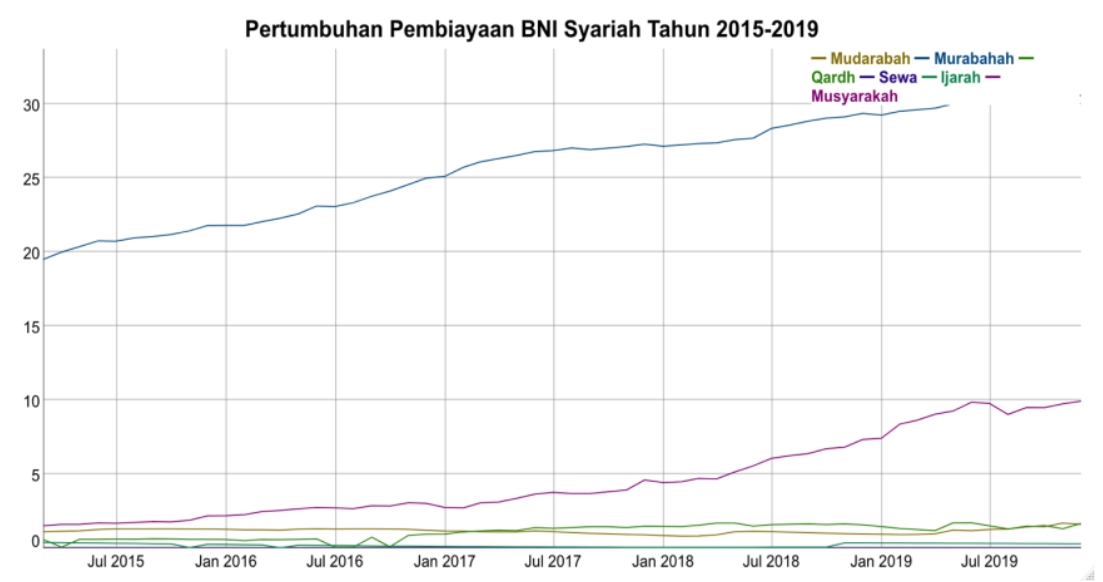

Gambar 1 Summary and Plot Series Pembiayaan

Gambar 1 menunjukkan grafik pergerakan data series umtuk jumlah dana yang disalurkan melalui pembiayaan untuk akad mudharabah,musyarakah, murabahah, qardh dan ijarah. Jumlah dana pembiayaan akad murabahah dan musyarakah setiap bulannya mengalami peningkatan setiap bulannya. Jumlah pembiayaan menggunakan akad murabahah paling banyak di tahun 2019. Untuk akad musyarakah pertumbuhannya dari tahun ke tahun meningkat namun tidak sebesar akad murabahah.Penyaluran dana melalui akad mudharabah perkembangannya flat dari awal tahun 2015 sampai dengan akhir tahun 2019. Untuk akad qardh cukup mengalami pertumbuhan hingga akhir tahun 2019. Pembiayaan akad ijarah di tahun 2015 menyalurkan dana cukup baik namun terjadi penurunan setiap bulannya sampai dengan Oktober 2018 namun pada November 2018 terjadi kenaikan drastis namun kembali menurun dibulan berikutnya hingga akhir tahun 2019. 


\section{Peramalan}

Peramalan data kuantitatif dilakukan dengan metode Jaringan Saraf Tiruan. JST merupakan pemodelan hubungan yang kompleks antara input dan output yang digunakan untuk menemukan pola pada data yang memiliki kelebihannya pada control area, prediksi dan pengenalan pola. Peramalan dilakukan pada masing-masing akad yang digunakan pada produk pembiayaan di BNI Syariah.

Data pembiayaan tidak dipengaruhi ataupun memiliki keterkaitan dengan variabel lain, sehingga rancangan model Jaringan Syaraf Tiruan (JST) yang digunakan dalam penelitian ini akan berbentuk time series, yaitu dengan melihat data hingga beberapatahun ke belakang.

\subsection{Mudharabah}

Peramalan pada akad mudharabah dilakukan selama satu tahun kedepan yaitu tahun 2020. Gambar 3 menunjukkan grafik hasil forecast mudharabah

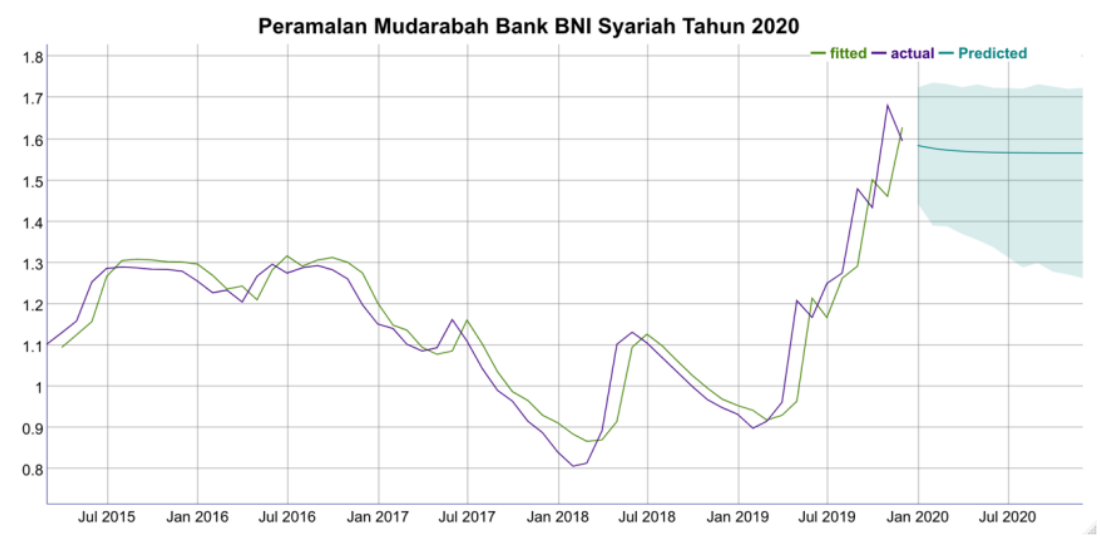

Gambar 3 Grafik Hasil Forecast Mudharabah

Gambar 3 memperlihatkan plot antara data series awal dengan data series dari hasil prediksi yang digunakan dalam analisis.

Tabel 3 Hasil Forecasting

\begin{tabular}{cccc}
\hline Tanggal & Forecast & Lower 95\% & Upper 95\% \\
\hline $01-01-2020$ & 1.584196 & 1.444879 & 1.724764 \\
$01-02-2020$ & 1.577431 & 1.390580 & 1.736673 \\
$01-03-2020$ & 1.573213 & 1.388574 & 1.733116 \\
$01-04-2020$ & 1.570536 & 1.369743 & 1.725637 \\
$01-05-2020$ & 1.568817 & 1.356189 & 1.732298 \\
$01-06-2020$ & 1.567706 & 1.339306 & 1.724195 \\
$01-07-2020$ & 1.566985 & 1.314937 & 1.723363 \\
\hline
\end{tabular}




\begin{tabular}{llll}
\hline $01-08-2020$ & 1.566515 & 1.289309 & 1.722161 \\
$01-09-2020$ & 1.566209 & 1.299707 & 1.732944 \\
$01-10-2020$ & 1.566009 & 1.278675 & 1.727173 \\
$01-11-2020$ & 1.565878 & 1.272087 & 1.721463 \\
$01-12-2020$ & 1.565792 & 1.263386 & 1.723948 \\
\hline
\end{tabular}

Tabel 3 menunjukkan data hasil peramalan beserta selang interval ramalan selama 1 tahun kedepan pada tahun 2020. Untuk penyaluran dana akad mudharabah cenderung menurun setiap bulan hingga akhir tahun 2020 yang berada diantara selang kepercayaan Lo_95 sampai dengan Hi_95 dengan selang kepercayaan yang berbeda-beda. Pada tabel 3 terlihat bahwa setiap bulan rentang selang kepercayaan semakin panjang. Hasil peramalan di awal tahun 2020 penyaluran dana menggunakan akad mudharabah sebesar Rp.1.580.000.000.000 dan cenderung menurun namun tidak terlalu besar setiap bulannya hingga akhir tahun 2020 pembiayaan akad mudharabah sebesar Rp. 1.560.000.000.000

\section{Tabel 4 Evaluasi Model}

\begin{tabular}{lllllll}
\hline Evaluasi Model & ME & RMSE & MAE & MPE & MAPE & MASE \\
\hline Mudarabah & $7.898027 \mathrm{e}-09$ & 0.06904791 & 0.04813927 & -0.356484 & 4.155869 & 1.034666
\end{tabular}

Berdasarkan output dari tabel 4 evaluasi model JST untuk mudharabah nilai MAPE 4.15\% menunjukkan peramalan sangat akurat karena nilai dibawah 10\%. Model ramal diperoleh dengan tingkat kesalahan akurasi ramal nilai RMSE sebesar 0.06904, nilai ME sebesar 7.8980, nilai MAE sebesar 0.048, MPE -0.3564 dan nilai MASE 1.034

Rendahnya minat masyarakat terhadap pembiayaan mudharabah dibandingkan akad jual beli (murabahah) mengilustrasikan operasional bank syariah belum sepenuhnya sesuai target. Keunggulan bank syariah yaitu pada prinsip bagi hasilnya karena inilah yang menjadi pembeda dengan perbankan konvensional. Hal ini disebabkan tingginya resiko bagi hasil menyebabkan pihak investor atau bank menjadi ragu untuk menyalurkan pembiayaan mudharabah karena masyarakat tidak bisa memberikan kepastian pendapatan baik dari segi jumlah maupun waktunya. 


\subsection{Musyarakah}

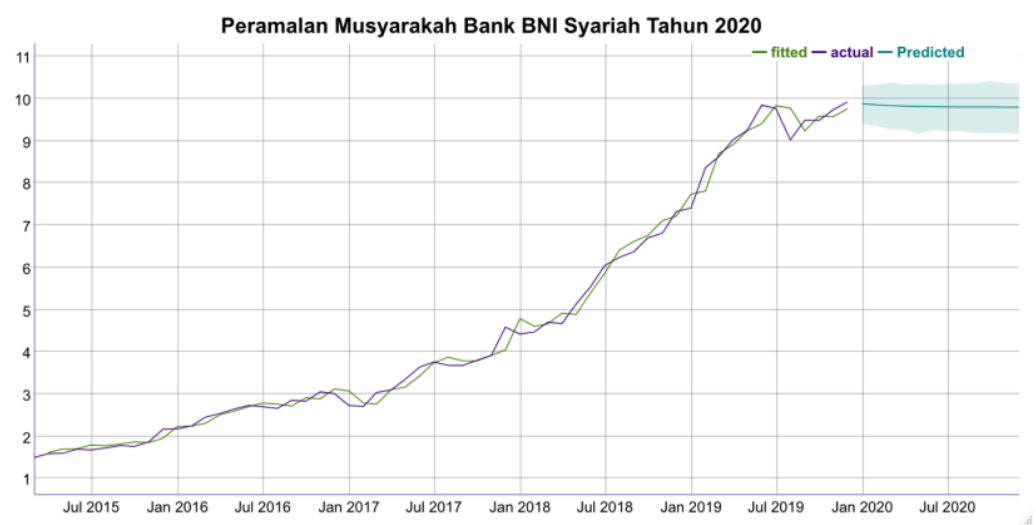

Gambar 4 Grafik Hasil Forecast Jumlah Musyarakah

Gambar 4 menunjukkan grafik data awal dari bulan Januari 2017 sampai dengan Desember 2019 dan pergerakan peramalan dari bulan Januari 2020 sampai dengan Desember 2020

\begin{tabular}{cccc}
\hline Tanggal & Forecast & Lower 95\% & Upper 95\% \\
\hline $01-01-2020$ & 9.877082 & 9.399110 & 10.30560 \\
$01-02-2020$ & 9.850393 & 9.358092 & 10.32850 \\
$01-03-2020$ & 9.832509 & 9.268662 & 10.37175 \\
$01-04-2020$ & 9.820474 & 9.259885 & 10.33692 \\
$01-05-2020$ & 9.812353 & 9.171057 & 10.34422 \\
$01-06-2020$ & 9.806862 & 9.248908 & 10.33832 \\
$01-07-2020$ & 9.803145 & 9.223309 & 10.34409 \\
$01-08-2020$ & 9.800626 & 9.225454 & 10.35437 \\
$01-09-2020$ & 9.798919 & 9.187064 & 10.35857 \\
$01-10-2020$ & 9.797761 & 9.180555 & 10.41131 \\
$01-11-2020$ & 9.796975 & 9.181537 & 10.36152 \\
$01-12-2020$ & 9.796442 & 9.162374 & 10.36003 \\
\hline
\end{tabular}

Tabel 5 menunjukkan data hasil peramalan selama satu tahun kedepan pada tahun 2020 untuk akad Musyarakah. Mulai awal tahun 2020 pada setiap bulannya hingga akhir tahun 2020 mengalami penurunan dengan selang kepercayaan yang hampir sama. Model peramalan divalidasi dengan nilai-nilai yang ditunjukkan pada tabel 6 evaluasi model menghasilkan nilai MAPE 3.60\% yang berarti dibawah $10 \%$ menunjukkan hasil peramalan sangat akurat. Model JST menghasilkan akurasi peramalan untuk akad mudharabah dengan nilai ME -1.81 nilai RMSE 0.216, nilai MAE 0.156, nilai MPE sebesar -0.263 dan MASE 0.768

Serupa dengan pembiayaan mudharabah, jumlah penyaluran dana menggunakan akad musyarakah kurang bertumbuh namun lebih baik dari mudharabah. Hasil forecast 
menunjukkan pembiayaan musyarakah cenderung menurun ini disebabkan resiko yang tinggi dalam pengembalian dana.

\section{Tabel 6 Evaluasi Model}

\begin{tabular}{lllllll}
\hline $\begin{array}{l}\text { Evaluasi } \\
\text { Model }\end{array}$ & ME & RMSE & MAE & MPE & MAPE & MASE \\
\hline Musyarakah & $-1.811475 \mathrm{e}-07$ & 0.2163261 & 0.1562934 & -0.2639744 & 3.607738 & 0.7689648 \\
\hline
\end{tabular}

\subsection{Murabahah}

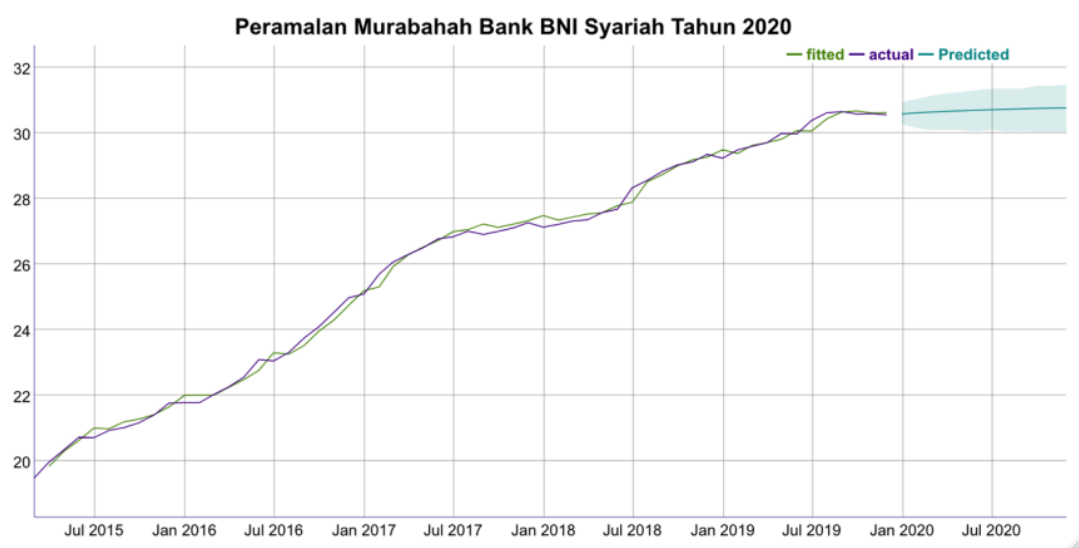

\section{Gambar 5 Grafik Hasil Forecast Murabahah}

Gambar 5 merupakan grafik hasil ramalan pada pembiayaan murabahah dari bulan Januari 2020 sampai dengan Desember 2020. Pada tabel 5 memperlihatkan hasil forecast dengan selang kepercayaan yang setiap bulannya cenderung sama. Awal tahun 2020 hasil peramalan menunjukkan jumlah pembiayaan sejumlah Rp. 30.580.000.000.000 dan hingga akhir tahun 2020 meningkat sebesar Rp. 30.760.000.000.000 Tabel 8 evaluasi model menunjukkan nilai MAPE $0.52 \%$ yang berarti model JST menghasilkan peramalan sangat akurat karena berada dibawah $10 \%$. Nilai akurasi peramalan pada model JST untuk akad murabahah sebesar ME -0.00146, nilai RMSE sebesar 0.1708, nilai MAE sebesar 0.1328, nilai MPE sebesar -0.01209 dan MASE 0.62269

Tabel 7 Hasil Forecast

\begin{tabular}{cccc}
\hline Tanggal & Forecast & Lower 95\% & Upper 95\% \\
\hline $01-01-2020$ & 30.58095 & 30.26305 & 30.93118 \\
$01-02-2020$ & 30.60863 & 30.14940 & 31.03306 \\
$01-03-2020$ & 30.63325 & 30.09106 & 31.13304 \\
$01-04-2020$ & 30.65513 & 30.09175 & 31.19628 \\
$01-05-2020$ & 30.67455 & 30.08868 & 31.24319 \\
$01-06-2020$ & 30.69177 & 30.04434 & 31.30185 \\
$01-07-2020$ & 30.70703 & 30.09244 & 31.34161 \\
$01-08-2020$ & 30.72055 & 30.04387 & 31.35443 \\
$01-09-2020$ & 30.73251 & 30.05004 & 31.34491 \\
\hline
\end{tabular}




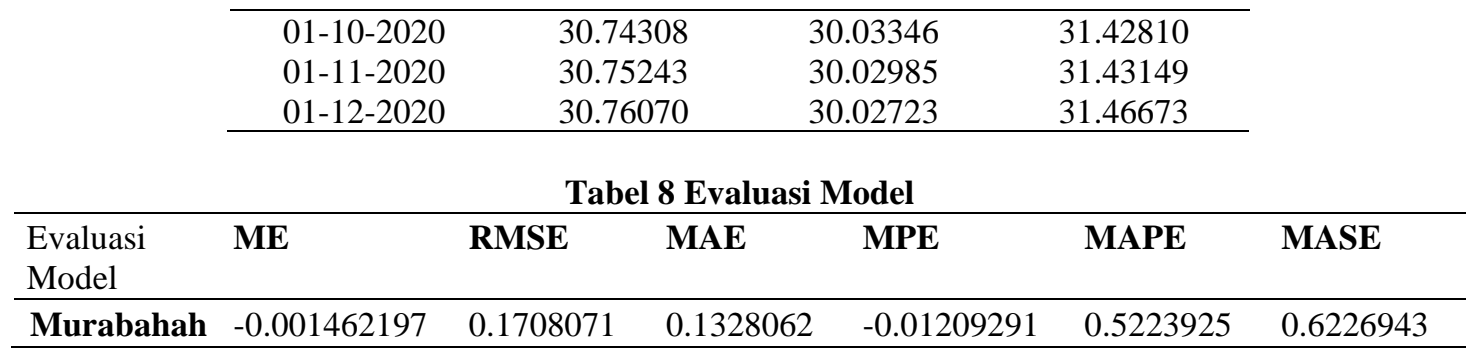

\subsection{Qardh}

Hasil peramalan pembiayaan dengan akad qardh dapat dilihat pada gambar 6 yang menunjukan data actual dan pergerakan data ramalan serta tabel 6 hasil ramalan dengan selang kepercayaan Lo_95 dan Hi_95

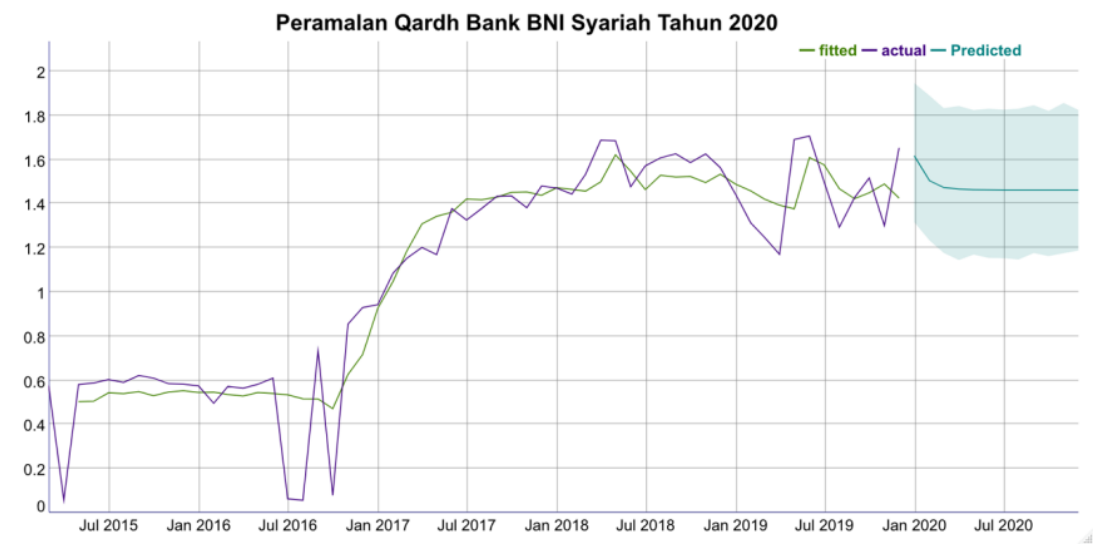

\section{Gambar 6 Grafik Hasil Forecast Jumlah Qardh}

Pergerakan data aktual pembiayaan Qardh berfluktuatif namun cenderung meningkat sampai akhir tahun 2019. Pada hasil peramalan terjadi penurunan jumlah dana yang disalurkan dan setiap bulannya pergerakan penurunan sama hingga bulan desember 2020 sejumlah Rp.1.460.000.000.000 Pada tabel 10 evaluasi model menunjukkan nilai MAPE pada tabel 10 sebesar $45.37 \%$ artinya peramalan dengan model JST untuk akad qardh masih dalam kewajaran karena berada daintara 20\% dan 50\%. Model peramalan memiliki nilai akurasi sebesar nilai ME 0.000211, nilai RMSE 0.1510, nilai MAE 0.1055, nilai MPE-34.58 dan nilai MASE 0.7669

Tabel 9 Hasil Forecast

\begin{tabular}{cccc}
\hline Tanggal & Forecast & Lower 95\% & Upper 95\% \\
\hline $01-01-2020$ & 1.616806 & 1.317155 & 1.947091 \\
$01-02-2020$ & 1.504616 & 1.234047 & 1.889886 \\
$01-03-2020$ & 1.473776 & 1.177515 & 1.833497 \\
$01-04-2020$ & 1.466231 & 1.145328 & 1.842675 \\
$01-05-2020$ & 1.463803 & 1.170062 & 1.824301
\end{tabular}




\begin{tabular}{llll}
$01-06-2020$ & 1.463002 & 1.154993 & 1.830930 \\
$01-07-2020$ & 1.462734 & 1.153522 & 1.826162 \\
$01-08-2020$ & 1.462645 & 1.147925 & 1.830580 \\
$01-09-2020$ & 1.462615 & 1.176688 & 1.846700 \\
$01-10-2020$ & 1.462605 & 1.162947 & 1.820885 \\
$01-11-2020$ & 1.462601 & 1.176413 & 1.856669 \\
$01-12-2020$ & 1.462600 & 1.187787 & 1.825362 \\
\hline
\end{tabular}

Tabel 10 Evaluasi Model

\begin{tabular}{lllllll}
\hline $\begin{array}{l}\text { Evaluasi } \\
\text { Model }\end{array}$ & ME & RMSE & MAE & MPE & MAPE & MASE \\
\hline Qardh & 0.0002110557 & 0.1510756 & 0.1055256 & -34.5851 & 45.37291 & 0.766994 \\
\hline
\end{tabular}

\subsection{Ijarah}

Peramalan pembiayaan ijarah dilakukan selama satu tahun kedepan selama tahun 2020 . Pada gambar 7 menunjukkan grafik data actual pembiayaan menggunakan ijarah yang fluktuatif dan cenderung menurun.



\section{Gambar 7 Grafik Hasil Forecast Ijarah}

Hasil peramalan mulai bulan Januari 2020 sampai dengan Desember 2020 pembiayaan ijarah menurun drastis dengan selang kepercayaan yang semakin panjang setiap bulannya yang terlihat pada Tabel 11 hasil forecast.

Tabel 11 Hasil Forecast

\begin{tabular}{cccc}
\hline Tanggal & Forecast & Lower 95\% & Upper 95\% \\
\hline $01-01-2020$ & 0.25243164 & 0.145679725 & 0.3559798 \\
$01-02-2020$ & 0.11273885 & 0.068176639 & 0.3877659 \\
$01-03-2020$ & 0.17056984 & 0.054466395 & 0.4017103 \\
$01-04-2020$ & 0.11340282 & 0.034308462 & 0.4085133
\end{tabular}




$\begin{array}{llll}01-05-2020 & 0.12874398 & 0.030187233 & 0.4061087 \\ 01-06-2020 & 0.09567324 & 0.017330842 & 0.4142710 \\ 01-07-2020 & 0.10428845 & 0.016553296 & 0.4108981 \\ 01-08-2020 & 0.08565048 & 0.003925068 & 0.4020430 \\ 01-09-2020 & 0.09132372 & 0.002824439 & 0.4077185 \\ 01-10-2020 & 0.08240764 & 0.000451898 & 0.4046982 \\ 01-11-2020 & 0.08588318 & 0.005222358 & 0.3878489 \\ 01-12-2020 & 0.08169904 & 0.006375858 & 0.3823452\end{array}$

Tabel 12 Evaluasi Model

\begin{tabular}{rllllll}
\hline Evaluasi Model & ME & RMSE & MAE & MPE & MAPE & MASE \\
\hline Ijarah & $2.585555 \mathrm{e}-05$ & 0.05045725 & 0.02618173 & -30.37163 & 41.08691 & 1.009494 \\
\hline
\end{tabular}

Tabel 12 untuk nilai MAPE sebagai evaluasi model $41.08 \%$ menunjukkan peramalan dalam kewajaran. Model JST memiliki nilai akurasi model sebesar nilai ME 2.5855 RMSE 0.0504 MAE 0.026 MPE -30.37 dan MASE 1.009

\section{Pembahasan}

Hasil peramalan yang dilakukan dengan meggunakan metode Jaringan Saraf Tiruan (JST) menunjukkan secara umum pembiayaan pada BNI Syariah mengalami peningkatan. Pertumbuhan pembiayaan BNI Syariah juga didukung dengan masifnya pergerakan pemerintah mengkampanyekan bank syariah. Untuk pembiayaan yang menggunakan akad murabahah mengalami kenaikan setiap bulannya hingga akhir tahun 2020. Hal ini didukung dengan masih besarnya potensi minat menggunakan akad murabahah karena minim resiko khususnya untuk produk pembiayaan rumah. Untuk pembiayaan yang menggunakan akad mudharabah dan musyarakah setiap bulannya hingga bulan Desember 2020 cenderung mengalami penurunan. Berbeda dengan akad qardh walaupun diawal tahun 2020 sedikit mengalami penurunan tetapi dipertengahan tahun sampai dengan akhir tahun pergerakannya stabil. Peramalan pada pembiayaan ijarah menunjukkan penurunan yang cukup drastis hingga akhir tahun 2020.

Portofolio pembiayaan bank syariah di Indonesia lebih didominasi murabahah untuk sektor konsumtif tidak terkecuali pada BNI Syariah. Padahal untuk membantu peningkatan perekonomian Indonesia penyaluran dana produktif sangat dibutuhkan melalui akad mudharabah dan musyarakah. Hal inipun sedang giat-giatnya dilakukan pemerintah untuk mendorong pertumbuhan pembiayaan syariah sesuai Master Plan Arsitektur Keuangan Syariah Indonesia (MAKSI) 2019-2024 (Keuangan, 2019). Mengantisipasi hasil peramalan mudharabah dan musyarakah selama tahun 2020 yang cenderung menurun, BNI 
Syariah perlu melakukan strategi untuk mendongkrak akad-akad tersebut. Program Linkage yang merupakan fasilitas pembiayaan BNI Syariah sebagai pemilik dana menyalurkan pembiayaan pada Lembaga Keuangan Syariah (LKS) seperti BMT, BPRS, KJKS dll untuk diteruskan ke konsumen akhir seperti UMKM yang sudah dilakukan oleh BNI Syariah perlu ditingkatkan dengan memperbanyak kerjasama dengan LKS. Pertumbuhan BPRS dan Koperasi bisa menjadi peluang bagi BNI Syariah untuk mendorong peningkatan penyaluran dana mudharabah dan musyarakah melalui program linkage ini. Dukungan dari pemerintah melalui regulasi juga dibutuhkan untuk meningkatkan penggunaan akad yang berorientasi pada sektor produktif karena saat ini tidak ada regulasi yang menargetkan bank-bank syariah tidak terkecuali BNI Syariah menyalurkan pembiayaan akad mudharabah dan musyarakah. Padahal keuntungan yang bisa diperoleh BNI Syariah bisa lebih besar melalui mudharabah dan musyarakah dibandingkan akad murabahah.

Untuk penyaluran dana melalui pembiayaan qardh di tahun 2020 tidak banyak bertumbuh dari tahun sebelumnya. Ini disebabkan masih kurangnya pemahaman masyarakat tentang akad-akad pembiayaan yang ada di bank syariah. BNI Syariah perlu lebih banyak melakukan literasi pada masyarakat. Akad ijarah yang menurun drastis dari tahun 2020 menuntut pihak BNI Syariah harus lebih agresif untuk melakukan literasi dan inovasi pada produk-produk pembiayaan. Potensi pembiayaan masih sangat luas, terutama pembiayaan Ijarah ini. Masih banyak masyarakat yang membutuhkan manfaat barang ataupun jasa namun tidak mampu untuk membelinya, hanya mampu untuk menyewa selama beberapa waktu. Dukungan dari pemerintah juga sangat dibutuhkan untuk mendukung pertumbuhan bank syariah khusunya BNI Syariah dalam menyalurkan dana pembiayaan ke masyarakat.

\section{KESIMPULAN}

Hasil dari penelitian menunjukaan model Jaringan Saraf Tiruan untuk meramal pembiayaan pada BNI Syariah selama tahun 2020 berhasil diimplementasikan. Jaringan Saraf Tiruan memiliki nilai akurasi peramalan yang tinggi dengan nilai error RMSE, MAPE, dan MASE yang minimum Hasilnya secara umum pembiayaan meningkat. Akad murabahah masih mendominasi proporsi pembiayaan dibandingkan akad murabahah, musyarakah dan qardh. Pembiayaan melalui akad ijarah mengalami penurunan cukup drastis hingga akhir tahun 2020. 
Pengembangan berikutnya pada penelitian ini perlu ditambahkan lebih banyak variabel dengan metode peramalan yang lain yang ditujukan untuk pengembangan pembiayaan Bank Syariah di Indonesia

\section{DAFTAR PUSTAKA}

BB, I. (2019). Sistem Peramalan Perkreditan Di Bank Muamalat Jember Dengan Menggunakan Metode Single Moving Average. Universitas Muhammadiyah Jember. Retrieved from http://repository.unmuhjember.ac.id/2135/

BNI Syariah. (2019). Laba Bersih BNI Syariah Triwulan 12019 Naik. Jakarta. Retrieved from https://www.bnisyariah.co.id/idid/beranda/berita/siaranpers/ArticleID/1719/Laba Bersih BNI Syariah Triwulan 1 2019 Naik

Keuangan, K. (2019, May). Ini Cara Pemerintah Tingkatkan Pertumbuhan Pembiayaan Syariah. Media Keuangan. Retrieved from https://www.kemenkeu.go.id/publikasi/berita/ini-cara-pemerintah-tingkatkanpertumbuhan-pembiayaan-syariah/

Momentum B. Islamic Finance Development Report 2018 Building Momentum. (2018). Retrieved from https://ceif.iba.edu.pk/pdf/Reuters-Islamicfinance-developmentreport2018

Ningrum, E. P., \& Samrotun, Y. C. (2019). NON PERFORMING FINANCING PADA BANK UMUM SYARIAH DI. Jurnal Ekonomi Pembangunan, 5(2), 75-85. Retrieved from https://journal.stiem.ac.id/index.php/jurep/article/view/422/311

Otoritas Jasa Keuangan. (2019). Statistik Perbankan Syariah-Mei 2019. Retrieved from https://www.ojk.go.id/id/kanal/syariah/data-dan-statistik/statistik-perbankansyariah/Pages/Statistik-Perbankan-Syariah---Mei-2019.aspx

RC, I., \& BD, S. (2018). Optimasi Fuzzy Time Series Menggunakan Algoritme Particle Swarm Optimization untuk Peramalan Nilai Pembayaran Penjaminan Kredit Macet. Jurnal Pengembangan Teknologi Informasi Dan Ilmu Komputer, 6(2), 2364-73.

S, Ayyubi L, Anggraeni AD, M. (2017). Pengaruh Bank Syariah terhadap Pertumbuhan Ekonomi di Indonesia The Effect of Islamic Banking to Economic Growth in Indonesia. Jurnal Al-Muzara'ah, 5(2), 88-106.

Sapar Sapar, Nuraeni Nonji, H. S. (2014). PENGARUH RISIKO PEMBIAYAAN MUDHARABAH TERHADAP PROFITABILITAS PADA PT.BANK SYARIAH MUAMALAT INDONESIA Tbk. Jurnal Ekonomi Dan Pembangunan STIE Muhammadiyah Palopo, 1(1). Retrieved from https://journal.stiem.ac.id/index.php/jurep/issue/view/2

Soekarni, M. (2014). Dinamika pembiayaan perbankan syariah dalam mengembangkan dunia usaha. Jurnal Ekonomi Dan Pembangunan, 22(1), 69-81.

Taufik, M. I. (2017). Analisis Pengaruh Pertumbuhan Pembiayaan Pada Perbankan Syariah berdasarkan Jenis Akad dan Penggunaan Terhadap Pertumbuhan Ekonomi Indonesia Periode 2011-2015. UIN Sunan Kalijaga. UIN Sunan Kalijaga. 